Lentera Pustaka 2 (2): 123-133, 2016

Copyright (O2016, ISSN: 2302-4666 print/ 2540-9638 online

Available Online at: http://ejournal.undip.ac.id/index.php/lpustaka

\title{
MANAJEMEN PERPUSTAKAAN SEKOLAH PADA SMA DAN SMK NEGERI SE-KOTA SINGARAJA: PERMASALAHAN DAN SOLUSI PEMECAHANNYA
}

\author{
Luh Putu Sri Ariyani ${ }^{* *}$ Wayan Mudana ${ }^{2)}$ \\ Jurusan D3 Perpustakaan, Fakultas Hukum dan Ilmu Sosial \\ Jl. Udayana No. 11 Singaraja, Bali \\ Universitas Pendidikan Ganesha \\ ${ }^{*}$ Korespondensi: putu.sri77@gmail.com
}

\begin{abstract}
[Title: School Library Management at SMA and SMK Negeri in Singaraja: Problems and Solutions] This research aims to understand the school library management at SMA and SMK Negeri in Singaraja, problems encountered by the school library, and the solutions in SMA and SMK in Singaraja; and the solutions proposed to improved its functions. The method of this research is a qualitative descriptive that focuses on the description and interpretation of behavior. Research carried out by several steps, namely; 1) data collection, 2) data reduction, and 3) data verification. The results shows that each SMA and SMK Negeri in Singaraja have adequate school library components eventhough there are still found several management problems; Constraints faced by school libraries at SMA and SMK in Singaraja, namely: a)The lack of collection diversity,b) the irregular collection arrangement, c)lack of facilities and infrastructure, $d$ ) half-hearted literacy, e) absence of professional librarians.Advice acts that can be done to improve library services in each school is first,conducting the collection development particularly in the selection of library materials; second, in collaboration with various stakeholders to the existence of the school library;third, the socialization of school literacy program for all students with teacher supervision; fourth, the school principal can hire a professional librarian to relate directly to the college scoring candidates librarian; and fifth,utilizing information and communication technology to increase the number of collections owned by the library.
\end{abstract}

Keywords: management; school libraries; information technology.

\begin{abstract}
Abstrak
Penelitian ini bertujuan untuk memahami pengelolaan perpustakaan SMA dan SMK Negeri se Kota Singaraja, masalah yang dihadapi dalam pengelolaan perpustakaan serta solusi atau saran tindak pemecahannya untuk meningkatkan fungsinya sebagai perpustakaan sekolah. Metode penelitian yang digunakan adalah metode deskriptif kualitatif yang berpusat pada deskripsi dan interpretasi atas perilaku yang ada. Penelitian dilakukan dengan mengikuti beberap tahapan seperti 1) pengumpulan data, 2) reduksi data, 3) verifikasi data. Hasil penelitian menunjukkan bahwa setiap perpustakaan sudah memiliki perpustakaan yang cukup memadai meskipun masih ditemukan beberapa masalah tata kelola seperti: a) kurangnya keberagaman koleksi, b) penataan koleksi yang tidak beraturan, c) kurangnya sarana dan prasaran, d) program literasi sekolah setengah hati, e) ketiadaan pustakawan professional. Saran tindak yang bisa diambil dalam penyelesaian masalah tersebut adalah: pertama, melakukan pengembangan koleksi dengan baik khususnya kegiatan seleksi koleksi perpustakaan.Kedua, bekerjasama dengan berbagai pihak yang berkepentingan terhadap keberadaan perpustakaan sekolah.Ketiga, sosialisas program literasi sekolah bagi semua siswa dengan pengawasan guru.Keempat, sekolah dalam hal ini kepala sekolah bisa mempekerjakan pustakawan profesional dengan berhubungan langsung ke perguruan tinggi yang mencetak caloncalon pustakawan.Kelima, Memanfaatkan perkembangan teknologi, informasi dan komunikasi untuk meningkatkan jumlah dan keragaman koleksi di perpustakaan.
\end{abstract}

Kata Kunci: pengelolaan; perpustakaan sekolah; teknologi informasi 


\section{Pendahuluan}

Salah satu sarana dalam menunjang proses belajar dan mengajar di sekolah adalah perpustakaan. Selama ini perpustakaan sekolah hanya dianggap sebagai unit kerja yang menyediakan bacaan guna menambah pengetahuan dan wawasan bagi murid, padahal perpustakaan sekolah merupakan bagianintegral pembelajaran yang dilaksanakan di sekolah. Penyelenggaraan perpustakaan sekolah diharapkan dapat sejalan dengan visi dan misi sekolah.Perpustakaan sekolah juga melakukan pengadaan bahan bacaan bermutu dan sesuai kurikulum, menyelenggarakan kegiatan yang berkaitan dengan bidang studi, dan kegiatan penunjang lain, misalnya berkaitan dengan peristiwa penting yang diperingati di sekolah (IFLA, 2006).

Perkembangan teknologi informasi dan komunikasi menempatkan informasi sebagai entitas penting dalam setiap sendi kehidupan manusia. Perpustakaan sekolah diharapkan mampu mengikuti perkembangan Teknologi Informasi dan Komunikasi (TIK) dalam hal menyediakan buku serta sumber informasi lainnya, seperti bahan audio-visual dan multimedia, serta akses informasi ke internet.Akses ke internet ini diperlukan untuk menambah dan melengkapi pengetahuan siswaterhadap sumber lain yang tidak dimiliki oleh perpustakaan sekolah. Namun harus diakui perpustakaan sekolah di tanah air masih menghadapi kendala dalam pengelolaannya.Minimnya perhatian manajemen sekolah, keterbatasan anggaran perpustakaan, ketersediaan tenaga professional pengelola perpustakaan, serta gedung, danperabot perpustakaanyangkurang memadai merupakan permasalahan klasik yang ditemui di sekolahsekolah (Nurjanah, 2014). Hal senada disampaikan oleh Woro Salikin dari Perpustakaan Nasional Republik Indonesia dalam Nurjanah (2014) bahwa berbagai problematika yang dihadapi oleh perpustakaan sekolah adalah masalah sumber daya manusia, anggaran dan mindset tentang pengelolaan perpustakaan. Kompas.com dalam Ariyani, dkk (2016) melaporkan bahwa sebanyak 55.545 sekolah belum memiliki perpustakaan. Sementara untuk SMP sebanyak 12.029, dan SMA sebanyak 8.904 sekolah masih belum memiliki perpustakaan. Tidak hanya sekolah yang berlokasi di daerah terpencil yang mengalami berbagai masalah pengembangan perpustakaan sekolah, namun tidak sedikit sekolah yang ada di daerah perkotaan juga mengalami hal yang sama.

Kota Singaraja adalah ibukota Kabupaten Buleleng, salah satu kota yang ada di Provinsi Bali yang dikenal sebagai kota pendidikan. Di lihat dari sejarahnya, Singaraja pernah menjadi ibukota Bali sebelum pindah ke Denpasar. Singaraja adalah pelopor sekolah-sekolah yang ada di Bali. Di kota ini masih berdiri sekolah tertua di Bali yaitu SMA Negeri 1 Singaraja di mana beberapa tokoh dan pemimpin Bali bahkan Nasional pernah mengenyam pendidikan di sana serta sekolah-sekolah pelopor lainnya. Sekolah menengah atas dan kejuruan Negeri di kota Singaraja sudah memiliki perpustakaan, namun masih ditemukan berbagai kendala dalam pengelolaan perpustakaan sekolah mereka. Dari paparan di atas, kajian ini berusaha mencari tahu sistem pengelolaan perpustakaan, kendala yang dihadapi perpustakaan sekolah di tingkat SMA dan SMK di kota Singaraja serta di akhir kajian diharapkan ditemukan solusi untuk mengatasi berbagai kendala tersebut. 


\section{Metode Penelitian}

Penelitian ini dilakukan dengan mempergunakan metode penelitian deskriptif kualitatif di mana yang dikumpulkan berupa pendapat, tanggapan, informasi, konsep-konsep dan keterangan yang berbentuk uraian dalam mengungkapkan masalah (Sulistyo-Basuki, 2010).Tujuan dari penelitian ini adalah mengungkap fakta, keadaan, fenomena, variabel dan keadaan yang terjadi saat penelitian berjalan dan menyuguhkan apa adanya (Sugiyono, 2012). Dengan demikian, jika peneliti ingin memahami suatu perilaku, maka pemahaman dari sudut pandang sang actor atas apayang mereka lakukan-pemahaman emik, menjadi mutlak adanya. Mereka adalah pelaku sehingga merekalah yang paling paham atas apa yang mereka lakukan. Pemahaman orang luar-pemahaman etik hanya bersifat melengkapi (Spradley,1972: 50-55; Strauss dan Corbin, 2003: 101). Pemaknaan sesuatu berkaitan dengan kebudayaan yangmereka miliki, mengingat bahwa kebudayaan tidak sekedar resep bertindak, tetapi juga pemberi makna terhadap tindakan sang actor (Geertz,1998: 35-85). Karena itulah, penelitian kualitatif pada dasarnya juga bersifat pengungkapan alasan maknawi dari tindakan aktor dalam suatu jaringan.

Penelitian inidilakukan pada 7 sekolah menengah atas (SMA/SMK) se Kota Singaraja. Sekolahsekolah tersebut adalah SMAN 1, SMAN 2, SMAN 3, SMAN 4, SMKN 1, SMKN 2, dan SMKN 3 Singaraja. Informandalam penelitianini ditunjuk secara purposive. Penunjukan iniditentukan berdasarkan pertimbangan bahwa sejauh mana mereka memahami masalah yang dikaji sebagaimana yang dirumuskan dalam masalah penelitian, posisi dalam struktur organisasi di perpustakaan sekolah serta pengalaman mereka dalam pengembangan perpustakaan sekolah masing-masing. Untuk itu,informan dalam penelitian ini terdiri dari Kepala Dinas Pendidikan Kabupaten Buleleng, Kepala Perpustakaan Sekolah SMA dan SMK Negeri di Kota Singaraja, pustakawan atau staff pengelola perpustakaan, kepala sekolah, kepala dinas pendidikan Kabupaten Buleleng, guru, dan beberapa siswa yang ditemui di perpustakaan sekolah tersebut.

Data yang dibutuhkan dalam penelitian ini dikumpulkan, dengan cara menerapkan berbagai teknik pengumpulan data, yakni:(a) Teknik Pengamatan (Observasi), (b) Teknik wawancara mendalam serta(c) Penggunaan Dokumen.

Data yang terkumpul diperoleh melalui penyebaran angket yang ditujukan bagi siswa untuk mengetahui persepsi mereka kepada perpustakaan di sekolah mereka. Di setiap perpustakaan sekolah dititipkan angket sebesar 25 lembar angket yang berisi pertanyaan seputar perpustakaan sekolah seperti pelayanan, koleksi, serta fasilitas yang dimiliki disana. Pada angket juga ditanyakan bagaimana saran mereka agar perpustakaan sekolah mereka menjadi tempat yang mereka harapkan. Pengumpulan data berlangsung pada bulan Agustus hingga bulan Oktober 2016. Sementara informan yang diwawancarai selama penelitian berjumlah 33 (tiga puluh tiga orang) terdiri dari kepala Dinas Pendidikan Kabupaten Buleleng, kepala perpustakaan, petugas atau staf perpustakaan, kepala sekolah atau wakil kepala sekolah 
yang pada saat wawancara kebetulan sedang berada di sekolah dan para siswa yang kebetulan berkunjung ke perpustakaan saat wawancara berlangsung.

Data yang terkumpul berwujud data kualitatif atau bisa pula dalam bentuk angka-angka. Dalam rangka lebih menjamin kesahihan data dilakukan teknik triangulasi data yaitu data dianalisis dengan melakukan serangkaian kegiatan, yakni pengumpulan data, penyajian data, reduksi data, dan menarik simpulan.

\section{Hasil dan Pembahasan}

Perpustakaan sekolah SMA dan SMK Negeri di Kota Singaraja terletak di lokasi yang cukup strategis di masing-masing sekolah di mana lokasinya gampang dijangkau oleh segenap warga sekolah. Setiap perpustakaan memiliki keunggulan dan kelemahannya masing-masing. Namun dari setiap keunggulan dan kelemahan yang dimiliki, hampir semua perpustakaan menerapkan manajemen atau tata kelola yang serupa antar satu perpustakaan dengan yang lainnya.

\subsection{Pengelolaan Perpustakaan SMA dan SMK Negeri se-Kota Singaraja}

Setiap sekolah memiliki alokasi dana untuk pengadaan buku di perpustakaan mereka. Sumber pengadaan cukup beragam yaitu (a) Dana BOS, dengan dana ini setiap sekolah secara rutin membeli buku untuk melengkapi koleksi di masing-masing perpustakaan. Pembelian diadakan secara rutin yaitu sekali setahun. Jumlah koleksi yang diadakan beragam di setiap sekolah tergantung dari kebijakan kepala sekolah masing-masing; (b) Dana komite yang diusulkan oleh guru kepada dewan komite sekolah untuk pembelian buku serta ditentukan berapa besaran dana yang diberikan pada saat rapat komite; (c) Sumbangan siswa yang akan tamat, diwajibkan untuk menyumbangkan buku-buku baru untuk menjadi koleksi perpustakaan; (d) Sumbangan alumni yang secara rutin menyumbangkan buku baik buku bekas yang kondisinya masih bagus maupun buku baru. Secara rutin setiap semester para alumni menyumbangkan buku sebagai bentuk kepedulian mereka terhadap kemajuan sekolahnya terutama untuk memajukan prestasi akademik. Sumbangan alumni tidak hanya terbatas pada buku tercetak, namun sudah memberikan sumbangan buku elektronik dengan berlangganan situs buku online dan dibayar oleh alumni. Kisah menarik tentang sumbangan koleksi dari alumni SMA N 1 Singaraja telah melahirkan berbagai gerakan lanjutan yang berasal dari alumni angkatan-angkatan sesudahnya. Salah satu alumni SMAN 1 Singaraja dari angkatan 1995 bahkan sedang menggagas perpustakaan digital untuk meningkatkan akses terhadap koleksi perpustakaan bagi siswa di luar jam sekolah. SDM dari alumni bahu membahu bekerjasama untuk mewujudkan perpustakaan yang lebih baik.

Koleksi yang berasal dari berbagai macam sumber kemudian diolah oleh perpustakaan sebelum dilayankan ke siswa. Klasifikasi koleksi yang digunakan di perpustakaan sekolahadalah klasifikasi DDC yang rata-rata diperoleh oleh staf perpustakaan pada saat mengikuti pelatihan pengelolaan perpustakaan. 
Setiap perpustakaan juga memiliki rak katalog yang berisi deskripsi masing-masing koleksi yang ada, namun masih terbatas pada koleksi lama. Selain katalog yang ditempatkan pada rak katalog, mereka juga membuat katalog yang diketik dan dicetak dalam bentuk lembaran untuk membantu siswa mencari koleksi yang diinginkan.

Untuk layanan sirkulasi, setiap siswa di tujuh sekolah yang ingin meminjam koleksi perpustakaan harus memiliki kartu dan mematuhi segala aturan yang sudah ditetapkan oleh perpustakaan. Syarat yang ditentukan perpustakaan sekolah untuk menjadi anggota perpustakaan sangat mudah. Rata-rata waktu peminjaman koleksi adalah satu minggu dengan jumlah denda bagi keterlambatan pengembalian adalah Rp. 100,00. (seratus rupiah)/hari. Rata-rata jam buka layanan sirkulasi adalah enam hari kerjamengikuti jam sekolah. Satu sekolah yaitu SMA Negeri 1 Singaraja bahkan bersedia buka hingga sore hari mengingat kegiatan akademik di sekolah tersebut berlangsung hingga sore hari.

Terhadap buku yang rusak, hampir semua perpustakaan sekolah belum memiliki program pelestarian koleksi sehingga koleksi yang kondisinya kurang baik atau rusak tetap dibiarkan berada di rak. Bahkan koleksi yang kerusakannya cukup parah tidak pernah mendapat perlakuan apapun dari pihak perpustakaan, baik itu berupa perbaikan maupun dikeluarkan dari perpustakaan. Hal ini mengakibatkan setiap sudut perpustakaan menjadi tempat buku rusak. Ketiadaan program perbaikan buku juga diikuti dengan ketiadaan program penyiangan koleksi. Hal ini mengakibatkan hampir di setiap perpustakaan ditemui buku-buku yang sudah tidak digunakan baik karena kurikulumnya sudah tidak berlaku maupun maupun yang sudah tidak tersirkulasi dalam kurun waktu yang cukup lama. Ketika ditanyakan kepada petugas mengenai penyiangan, mereka serempak menjawab bahwasannya tidak berani mengeluarkan atau membuang buku-buku yang sudah tidak digunakan karena takut kena sangsi. Pustakawan di SMA N 4 Singaraja bahkan mengatakan "buku-buku yang terus saja bertambah telah memenuhi lantai perpustakaan mengingat sudah tidak ada lagi tempat untuk menaruhnya dalam rak. Sementara tidak ada satu pun buku yang boleh dihilangkan." Alasannya adalah karena takut disalahkan. Dari apa yang dikemukakan petugas di SMA N 4 Singaraja terlihat bahwa sekolah tersebut tidak pernah memikirkan tentang adanya penyiangan untuk menyingkirkan koleksi yang sudah tidak pernah dibaca lagi. Ada juga petugas perpustakaan yang tidak berani melakukan penyiangan karena dilarang kepala sekolah. Alasannya adalah karena takut buku tersebut dipakai lagi apabila kurikulumnya kembali seperti semula. Apabila dilihat dari kondisi tersebut, petugas tidak bisa dipersalahkan mengingat pemeritah kita yang seringkali berubah kebijakannya ketika kementrian berganti menteri. Kondisi nihilnya kegiatan penyiangan koleksi mengakibatkan ruang perpustakaan semakin sempit. Ketika ditanyakan kepada kepala sekolah pun, jawaban yang diterima tetap sama, tidak berani menyingkirkan koleksi lama terutama yang dibeli atau diperoleh dari pemerintah. Seperti yang dikemukakan oleh wakil kepala sekolah bagian kurikulum SMA N 2 Singaraja bahwasannya: 
"kami memilih untuk sebisa mungkin menambah rak untuk menempatkan buku-buku baru. Kami tidak mau ada masalah di kemudian hari kalau buku-buku lama ini dibuang atau dihibahkan. Kan semua ini dari pemerintah, takut nanti jadi masalah di kemudian hari. Semoga saja masih ada yang mau membaca, toh kandungan pengetahuannya masih bisa berguna."

Dari ungkapan di atas terlihat bahwa pihak sekolah tidak keberatan menyimpan buku-buku lama dan memilih menambah rak untuk menempatkan buku baru tanpa menggusur buku lama.

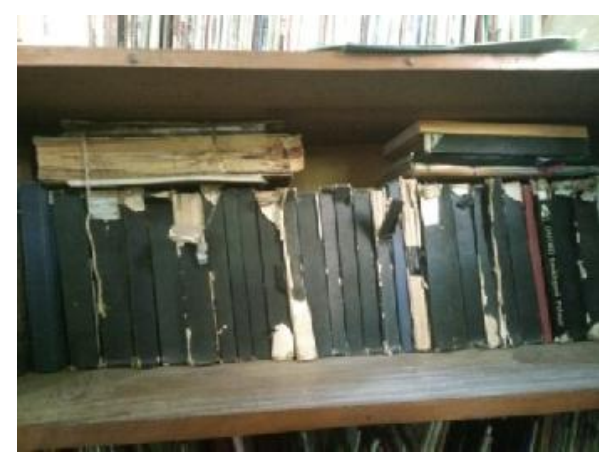

Gambar 1.Salah satu sudut perpustakaan yang penuh dengan koleksi usang dan tidak pernah disentuh oleh pengunjung perpustakaan sekolah

Sumber: Luh Putu Sri Ariyani (2016)

\subsection{Kendala Pengelolaan Perpustakaan}

Dari hasil wawancara dengan siswa SMA dan SMK Negeri se-Kota Singaraja menunjukkan bahwa minat mereka untuk berkunjung ke perpustakaan sangat tinggi di setiap sekolah, terbukti dari setiap kunjungan ke masing-masing perpustakaan selalu ditemukan dalam kondisi ramai terutama pada saat jam-jam kosong maupun saat jam istirahat. Namun di saat bersamaan para siswa juga mengemukakan keluhan atau perasaan kurang puas terkait dengan perpustakaan yang mereka miliki.Selain dari siswa, keluhan juga dikemukakan oleh staf perpustakaan maupun guru terkait dengan kendala-kendala yang dihadapi dalam pemanfaatan perpustakaan sekolah mereka. Di bawah ini dipaparkan kendala-kendala yang dikemukakan oleh para siswa, guru, dan staf perpustakaan di masing-masing perpustakaan sekolah

\subsubsection{Kurangnya keberagaman koleksi perpustakaan}

Sebagian besar koleksi perpustakaan SMA dan SMK Negeri se Kota Singaraja didominasi oleh buku pelajaran atau buku paket bagi siswa baik kurikulum lama maupun kurikulum baru yang masih berlaku.Namun di beberapa sekolah seperti SMA N 1 dan SMA N 2 sudah memiliki koleksi yang cukup beragam. Pengadaan buku-buku yang ada di kedua perpustakaan tersebut merupakan usulan dari siswa yang dijaring melalui kuesioner, buku minat yang disediakan di perpustakaan, serta usulan dari MGMP (Musyawarah Guru Mata Pelajaran) terkait buku-buku penunjang pembelajaran. Setelah proses penjaringan minat siswa, selanjutnya tim pengadaan memesan dan membeli buku yang dimaksud. Hukum ke lima perpustakaan yang dikemukakan oleh Ranganatan menyatakan bahwa library is a growing organism. Dalam konteks pengembangan koleksi, perpustakaan semestinya berkembang 
mengikuti perkembangan teknologi informasi. Dari ketujuh perpustakaan sekolah negeri yang ada di kota Singaraja, baru SMA Negeri 1 Singaraja yang memiliki koleksi elektronik yang dilanggan melalui scribd.com yang merupakan sumbangan alumni SMA N 1 Singaraja angkatan 1995. Koleksi elektronik ini tidak bisa diakses dengan baik apabila tidak ada koneksi internet sehingga keberadaan internet menadi keniscayaan bagi sekolah yang ingin mengembangkan koleksi selain buku tercetak. Selain SMA N 1 Singaraja, belum ada sekolah yang memiliki koleksi elektronik. Koleksi yang kurang di stiap perpustakaan sekolah juga disebabkan karena kurangnya dana yang diperuntukkan untuk pembelian koleksi. Dari 7 sekolah yang menjadi lokasi penelitian ini berlangsung, tidak satu sekolah pun memberikan jawaban pasti terkait nominal dana yang dipeuntukkan bagi pengadaan koleksi perpustakaan. Sehingga peneliti mengasumsikan jikalau dana untuk pengadaan koleksi memang kecil setiap tahunnya. Kondisi ini tentu memprihatinkan mengngat perpustakaan merupakan sarana penunjang penting bagi kemajuan penddikan anak didik di sekolah.

\subsubsection{Penataan koleksi yang belum teratur}

Penataan koleksi di beberapa sekolah belum teratur. Terbukti seperti SMK Negeri 1 dan SMA Negeri 3 masih menempatkan bukunya secara acak antara subjek yang satu dengan yang lainnya. Bahkan ada buku yang sekiranya tidak jelas klasifikasinya ditempatkan di rak paling bawah dan ditumpuk bersama buku lainnya. Kondisi buku seperti ini menyulitkan siswa dalam menemukan buku yang diinginkan sehingga usaha untuk membaca dan meminjam buku di perpustakaan menjadi terhambat. Hasil angket di SMA N 3 Singaraja menunjukkan 80\% siswa yang berkunjung perpustakaan tidak menemukan koleksi yang dibutuhkan tanpa dibantu oleh petugas. Yang paling sering mereka batal meminjam buku apabila petugas perpustakan tidak berada di tempat saat mereka hendak meminjam buku. Dari pengamatan kancah, sekolah ini merupakan sekolah dengan kondisi paling menyedihkan dalam hal penataan koleki. Sementara penataan koleksi di perpustakaan SMK N 1 singaraja lebih baik dari SMA N 3 mengingat petugas perpustakaan banyak dibantu siswa dalam penempatan koleksi sehingga kondisi ruangan perpustakaan terlihat lebih rapi meskipun tata letak buku masih ada yang tidak beraturan. Koleksi perpustakaan SMK N 2 Singaraja tertata dengan baik sehingga secara sepintas, perpustakaan ini sangat rapid an teratur, namun ketika hendak mencari buku yang diinginkan, siswa kesulitan menemukannya. Ketika ditanyakan kepada pustakawan, mereka menjawab kalau tidak ada masalah dengan penataan dan nomor panggil, mengingat pustakawan selalu menemukan buku yang dicari oleh siswa. Setelah diteliti lebih mendalam ke rak masing-masing koleksi, ternyata ada kelas-kelas buu yang tidak sesuai dengan klasifikasi buku yang baku. Usut punya usut ternyata staf perpustakaan mlakukan pengolahan buku tanpa menggukan DDC asli atau DDC ringkas keluaran Perpusnas, namun mereka menggunakan buku "Pengelolaan Perpustakaan Sekolah" karya Noerhayati. Kondisi ini tentu tidak sesuai dengan pengelolaan perpustakaan yang berlaku, sehingga apabila hal ini diteruskan maka buku yang mereka miliki tidak bisa ditata sesuai subjek buku yang ada. 


\subsubsection{Minimnya sarana dan prasarana}

Masalah yang ditemukan di hampir semua perpustakaan adalah minimnya kepemilikan sarana dan prasarana seperti meja dan kursi baca serta rak untuk menata koleksi. Kurangnya jumlah meja dan kursi yang tersedia menyebabkan siswa enggan datang dan membaca di perpustakaan. Jumlah siswa yang bisa ditampung di perpustakaan sangatlah sedikit, yaitu tidak lebih dari 20 orang, bahkan beberapa sekolah hanya bisa menampung kurang lebih 10 sampai 15 orang. Minimnya jumlah rak menambah kacunya penataan buku di perpustakaan. Pengadaan buku tidak diimbangi dengan peyediaan rak koleksi. Sehingga buku yang jumlahnya cukup banyak tidak mendapatkan tempat untuk ditata di dalam rak. Kondisi ini pada akhirnya memaksa staf perpustakaan untuk menumpuk buku yang mereka beli di atas meja baca yang diperuntukkan bagi pengunjung untuk membaca. Situasi seperti ini pada akhirnya semakin mempersempit peluang siswa untuk menikmati bacaan secara tenang dan menyenangkan karena meja tempat mereka membaca dikepung oleh tumpukan buku. Secara tidak langsung kondisi tersebut menyebabkan perpustakaan semakin sepi dari pengunjung.

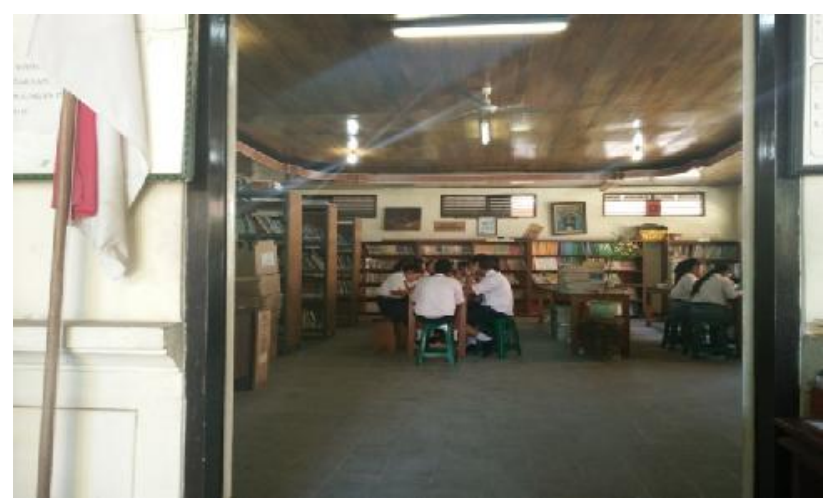

Gambar 2. Minimnya jumlah meja dan kursi baca menyebabkan perpustakaan hanya bisa me nampung siswa secara terbatas (Sumber: Luh Putu Sri Ariyani, 2016)

\subsubsection{Pembinaan Minat Baca setengah Hati}

Hasil wawancara dengan pustakawan, siswa dan guru di 7 sekolah diperoleh data bahwasannya hampir semua guru mata pelajaran Bahasa Indonesia mewajibkan siswa untuk membaca ke perpustakaan dan mengerjakan tugas yang diberikan guru. Hal ini bagus bagi perkembangan minat baca siswa dalam memperkaya wawasan mereka akan bacaan. Semua guru sepakat hal tersebut berguna untuk meningkatkan minat baca serta minat berkunjung ke perpustakaan mengingat pemberian tugas mewajibkan siswa untuk mengumpulkan bahan pelajaran dari sumber di perpustakaan. Namun slah seorang staf perpustakaan di SMA Negeri 4Singaraja mengemukakan bahwa meskipun ada kewajiban membaca koleksi perpustakaan, masih banyak siswa yang mengakses informasi melalui gadget atau sejenisnya. Sementara di SMKN 1 guru-guru yang memberikan tugas ke perpustakaan belum 
sepenuhnya mampu mengontrol kegiatan siswanya di perpustakaan sehingga ketika ada tugas dari guru yang dikerjakan di perpustakaan, siswa masih banyak bermain daripada membaca. Hal senada diungkapkan oleh Kepala Dinas Pendidikan Kabupaten Buleleng, I Gede Suyasa, M.Pd. yang menyatakan bahwasannya mewajibkan siswa membaca ke perpustakaan tidak akan berhasil baik apabila tidak diikuti dengan review dan penilaian dari guru itu sendiri. Beliau mengungkapkan bahwasannya para guru masih setengah hati menerapkan program literasi sekolah.

\subsubsection{Ketiadaan pustakawan profesional}

Di setiap lini pekerjaan diperlukan tenaga professional untuk menghasilkan layanan yang memadai. Dalam konteks perpustakaan belum satupun dari ke tujuh ke tujuh perpustakaan SMA dan SMK Negeri di Singaraja memiliki tenaga pustakawan professional. Beberapa perpustakaan bahkan masih dikelola oleh guru yang kebetulan ditugaskan di perpustakaan. Mengingat petugas perpustakaan merangkap sebagai guru, pada saat guru tersebut menunaikan kewajiban mengajar perpustakaan akan dibiarkan kososng tanpa penjaga. Hal ini tentu menjadi kendala bagi siswa yang kebetulan kelasnya kosong atau siswa yang memiliki jam mata pelajaran agama berbeda dari temantemannya untuk memanfaatkan perpustakaan secara maksimal karena perpustakaan dalam kondisi kosong atau tutup. Kondisi ini tentu menghambat upaya meningkatkan minat siswa untuk membaca dan belajar di perpustakaan dan yang lebih fatal ada banyak siswa yang menyatakan enggan datang ke perpustakaan karena seringkali merasa kecewa ketika tiba di perpustakaan dan mendapati perpustakaan tutup.

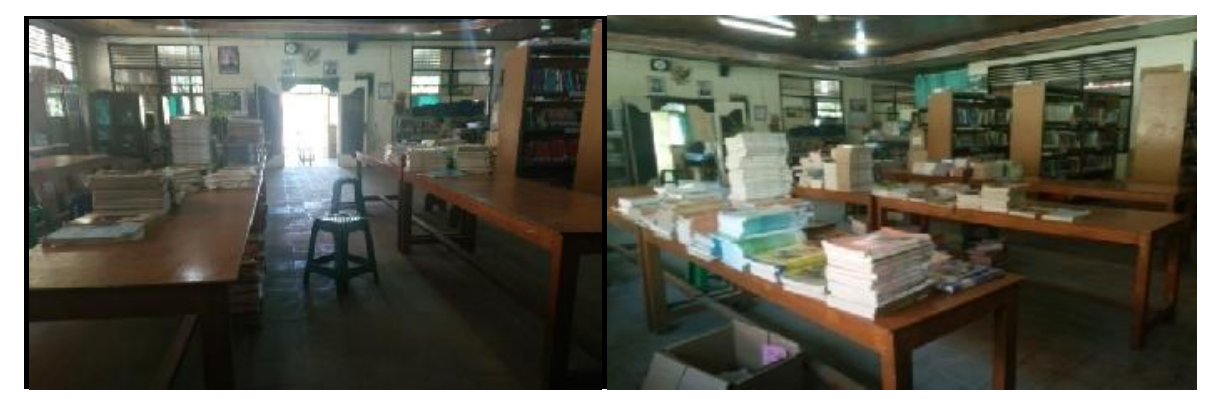

Gambar 3.Buku-buku yang ditumpuk di atas meja akibat kurangnya jumlah rak yang dimiliki perpustakaan (sumber: Luh Putu Sri Ariyani, 2016)

\subsection{Saran Tindak Perbaikan Perpustakaan}

Untuk memecahkan permasalahan yang dihadapi perpustakaan sekolah diperlukan kiat-kiat yang sesuai baik secara etik maupun emik. Kiat yang berbasis kepada pengetahuan etik merupakan pemecahan yang berasal dari pemanfaatan teori-teori baku dalam bidang perpustakaan. Disamping itu perlu pula dicermati gagasan emik yang bersumber langsung dari informan atau pelaku budaya sendiri (Pelto and Pelto, 1970). 
Berdasarkan temuan kancah, upaya peningkatan kualitas layanan dapat dilakukan dengan upayaupaya sbb: pertama, melakukan pengembangan koleksi dengan baik khususnya kegiatan seleksi koleksi perpustakaan. Koleksi yang disediakan bagi siswa SMA dan SMK adalah koleksi yang jenisnya sangat beragam yang peruntukannya ditujukan bagi remaja yang menginjak usia dewasa. Pada usia ini, para siswa sedang menata masa depannya untuk mempersiapkan diri mereka menapaki dunia perguruan tinggi sehingga siswa SMA dan SMK dipersiapkan untuk mulai belajar mandiri yang diawali dengan memanfaatkan berbagai koleksi perpustakaan sekolahnya. Kondisi seperti ini diperlukan petugas perpustakaan yang memahami kebutuhan siswa akan bacaan yang cocok bagi usianya.Kedua, bekerjasama dengan berbagai pihak yang berkepentingan terhadap keberadaan perpustakaan sekolah. Pihak-pihak yang bisa dilibatkan dalam pengembangan perpustakaan sekolah adalah komite sekolah. Dengan mengusulkan agar dana yang berasal dari komite dapat dimanfaatkan untuk pengadaan, perpustakaan dapat menambah jumlah sarana dan prasarana di perpustakaan seperti pengadaan rak untuk penataan buku yang lebih baik, meja dan kursi untuk tempat duduk siswa dalam membaca di perpustakaan. Selain dengan komite, kerjasama juga bisa dilakukan dengan alumni yang memiliki kepedulian terhadap kemajuan sekolah mereka. Kerjasama dengan alumni bisa dilakukan melalui sumbangan buku, sarana prasaran maupun dalam bentuk lainnya. Kerjasama dengan perpustakaan umum juga penting dilakukan untuk melakukan control atas pengelolaan yang sudah dilakukan sehingga perpustakaan selalu dalam kondisi baik dan nyaman.Ketiga, sosialisas program literasi sekolah bagi semua siswa dengan pengawasan guru. Dengan menggerakkan kemampuan literasi siswa, maka siswa akan memiliki kemampuan lebih dalam memecahkan berbagai masalah baik masalah akademik maupun sehari-hari. Mengingat kemampuan literasi menyangkut beberapa macam keterampilan, maka sekolah perlu membuat program rutin terkait keterampilan-keterampilan tertentu seperti keterampilan menggunakan computer, komunikasi, dan lain sebagainya agar bisa dikembangkan siswa untuk bekal masa depan mereka. Kemampuan literasi teknologi, informasi dan komunikasi bagi siswa, selain bermanfaat bagi pengembangan kemampuan individu mereka juga berguna bagi perpustakaan. Kemampuan teknologi, informasi dan komunikasi yang baik dapat digunakan untuk meningkatkan jumlah koleksi perpustakaan dengan penguasaan keterampilan pencarian informasi di internet baik oleh guru, pustakawan maupun siswa. Dengan demikian perpustakaan akan selalu memiliki koleksi beragam dan mutakhir bagi para stake hodernya.Kemampuan literasi ini juga berguna untuk mengatasi keterbatasan modal finansial di perpustakaan melalui pengadaan database yang tidak berbayar atau gratis. Keempat, sekolah dalam hal ini kepala sekolah bisa mempekerjakan pustakawan profesional denganberhubungan langsung ke perguruan tinggi yang mencetak calon-calon pustakawan. Hal ini sangat penting karena pekerjaan pustakawan tidak hanya terbatas pada menata koleksi dan layanan sirkulasi. Yang lebih penting adalah, pustakawanlah yang paling mengetahui bagaimana agar pemakai dalam hal ini siswa bisa memanfaatkan perpustakaan sekolahnya secara maksimal sebagai sumber belajar dan pusat rekreasi untuk mendukung prestasi akademik di sekolah. Pustakawan juga yang paling tahu programprogram yang tepat bagi stake holdernya.Kelima, Memanfaatkan perkembangan teknologi, informasi dan 
komunikasi untuk meningkatkan jumlah dan keragaman koleksi di perpustakaan. Keterampilan literasi informasi pustakawan bisa dimanfaatkan dalam hal pengadaan koleksi elektronik melalui berbagai situs yang ada di internet.

\section{Simpulan}

Perpustakaan sebagai organism yang berkembang senantiasa harus berubah sesuai dengan perkembangan teknologi. Pustakawan profesional sangat dibutuhkan di setiap jenis perpustakaan, selain untuk menghimpun berbagai informasi yang berguna bagi pemakainya juga harus mampu menjadi problem solver bagi semua stake holdernya. Sebagai salah satu sumber belajar, perpustakaan harus mampu menyediakan berbagai alternative pemenuhan kebutuhan informasi para stake holder agar menjadi salah satu acuan pemecahan berbagai masalah akademik. Pustakawan juga bisa menjadi partner guru dalam penyediaan bahan tambahan pengetahuan siswa di dalam kelas. Pustakawan juga bisa berkolaborasi dengan guru untuk membumikan program literasi sekolah.

\section{Daftar Pustaka}

Ariyani, L.P.S, dkk. 2016. Pelatihan Literasi Informasi bagi Pengelola Perpustakaan SMA dan SMK se Kota Singaraja. Laporan Pengabdian Masyarakat tidak diterbitkan.

Geertz, Clifford. 1998. After The Fact. Dua Negeri, Empat Dasawarsa, Satu Antropolog. Yogyakarta: LkiS

IFLA. 2006. Pedoman Perpustakaan Sekolah IFLA. Diunduh tanggal 29 Maret 2016 pada http://www.ifla.org/VII/s11/pubs/school-guidelines.htm

Nurjanah. 2015. Problematika Problematika Perpustakaan Sekolah (Study Kasus Di Smp Negeri 3 Mertoyudan Kabupaten Magelang). TesisProgramPascasarjanaUINSunanKalijaga,tidak diterbitkan.

Pelto, Pertti J dan Gretel H. Pelto. 1984. Anthropological Research.. Cambridge: Cambridge University Press.

Spradley, James. P. 1972. Culture and Cognition. Rules, Maps and Plan. Chandler Publishing Company.

Strauss, Anselm dan Juliet Corbin. 2003. Dasar-dasar Penelitian Kualitatif Tatalangkah dan Teknikteknik Teoritisasi data. [Penerjemah: Muhammad Shodiq \& Imam Muttaqien]. Yogyakarta: Pustaka Pelajar.

Sugiyono. 2012. Memahami Penelitian Kualitatif. Bandung: Alfabeta.

Sulistyo-Basuki. 2010. Metode Penelitian. Jakarta: Penaku.

Undang-undang Perpustakaan. 2007. UU RI No. 43 tahun 2007 Tentang Perpustakaan.

Undang-undang Sisdiknas. 2003. UU RI Nomor 20 tahun 2003 tentang Sistem Pendidikan Nasional (Sisdiknas). 